\title{
A Pragmatic Approach for Determining Overfishing and Overfished Condition for Assessing Data-deficient Fisheries
}

\author{
Chang-Ik ZHANG $^{\dagger} \cdot$ Jae-Min LEE \\ $\left({ }^{\dagger}\right.$ Pukyong National University $\cdot$ Seoul National University)

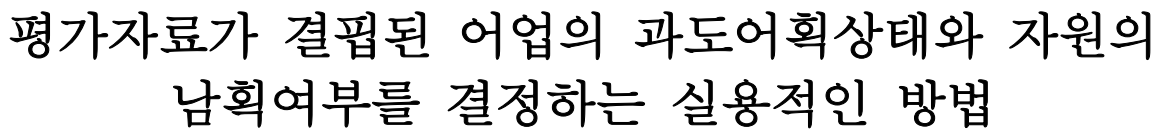 \\ 장창익 ${ }^{\dagger} \cdot$ 이재민 \\ ( ${ }^{+}$부경대학교 - 서울대학교)
}

\begin{abstract}
본 연구는 어업자원이 건강한 상태에 있는지 아니면 남획된 상태에 있는지를 판단하고, 현재 어업 활동이 과도한지 아닌지를 판단하기 위한 간단하고 실용적인 방법을 개발하였다. 자원평가를 수행 시에는 고가의 자료와 고도의 기술력이 요구되는 어려움이 있는데, 특히 소규모 어업과 다종어업에 서 어려움이 더욱 심하다. 본 연구에서 개발된 방법은 어업자원의 구체적인 상태와 어업활동의 객관 적인 상태를 고려해서 어업자원을 보존하고 어업활동을 규제할 수 있는 실용적이고 신뢰할 수 있는 방법이다. 예를 들어, 자원량과 어획사망률을 추정하는데 필요한 자료가 없거나, 추정할 수있는 과학 적 능력이 부족한 경우에는, 자원량을 대용해서 단위노력당어획량을 사용하고 어획사망률을 대용해 서 어획노력량 자료를 사용할 수 있다. 본 연구에서 제시한 방법의 실현가능성과 유용성을 입증하기 위하여, 복수어종으로 집계된 어획량과 어획노력량 만으로 된 경우나 또는 개체군 특성치 정보와 체 장자료 만이 이용 가능한 경우에 대해 적용하였다. 이 방법은 수산자원의 보존이라는 전지구적 목표 를 달성하는데 있어서, 필요한 자원상태와 어업상태를 판단해서 어획활동을 규제하고 조정할 수 있 는 유용한 방법이 될 수 있을 것으로 보인다.
\end{abstract}

Key words : Overfished condition, Status of overfishing, Catch, Fishing effort, Surrogate of biomass, Surrogate of Fishing mortality, Aggregated multi-species, Fish length

\section{I . Introduction}

\section{Definition of overfishing}

Overfishing can be defined in a number of different ways. Also, overfishing can be explained by a number of types such as biological overfishing and economic overfishing. The biological overfishing can be further explained by growth overfishing, recruitment overfishing and ecosystem overfishing (Hilborn, 2012). However, the authors confine the meaning of biological overfishing in this study to a specific context and define it simply as 'fishing with a high intensity to reduce the stock levels to such a condition that they no longer support a

† Corresponding author : +82 516295892 , cizhang@pknu.ac.kr

* This work was supported by a research grant of Pukyong National University (2013). 
reasonable quantity of fish for harvest'. Therefore, biological overfishing will cause low biological reproduction rates, low spawning biomass levels, and eventually depletion of exploitable fish stocks.

\section{Status of overfishing}

The threat of overfishing is regarded as one of the three basic and interrelated problems of modern fisheries, together with overcapitalization or over-expansion of fishing fleets and the negative consequences of fisheris on the survival of marine life and associated habitats. Many fisheries are managed in a setting where full information lacks on, for example, fish population dynamics, interactions among species, effects of environmental factors on fish populations, and the effects of other human activities on fish stocks. Recogniton of the inherent uncertainty and its potential consequences have led to the adoption of the precautionary approach in various international fora. The precautionary approach is focused on reducing the likelihood of fisheries having adverse effects on marine resources and host ecosystems (Zhang and Marasco, 2003).

The FAO publishes a report that summarizes the status of commercially important fish stocks. According to the most recent FAO (2010) report, the percentage of under-exploited and moderately-exploited stocks decreased from $40 \%$ in 1974 to only $15 \%$ in 2008, while that of over-exploited, depleted and recovering from depletion increased from $10 \%$ in 1974 to $32 \%$ in 2008. These figures give us an important warning signal. The percentage of under-exploited and moderately-exploited stocks was $20 \%$ in 2006 , but it substantially declined to $15 \%$ in 2008 just within the period of two years, indicating further potential declines in a short time span in the future.
Anonymous (2008) reported a study titled The Sunken Billions which concludes that marine capture fisheries are an underperforming global asset. The study shows that the difference between the potential and actual net economic benefits from marine fisheries is in the order of $\$ 50$ billion per year. The report also stressed that improved governance of marine fisheries could capture a substantial part of this $\$ 50$ billion annual economic loss, and that reforms of the fisheries sector could generate considerable additional economic growth and alternative livelihoods, both in the marine economy and other economic sectors by addressing various political, social, and economic costs (Anonymous, 2008).

Therefore, it is necessary to develop an approach to determine whether a fish stock is in a healthy condition or in an over-fished condition, and whether the current fishing operation remains in the status of overfishing or not by examining the existence of effective fisheries management systems in the oceans at issue. In fact, there are 584 stock or species groups where there are at least general catch trends available that can be used for the purpose of monitoring the relevant resource status. Stock assessment information is also available for 441 (76 percent) stock or species groups. These species produced about 80 percent of total marine catches in 2002 (FAO 2005). The remaining 143 stock or species groups, for which there is no assessment information available or any available information is not sufficiently reliable to allow an estimate of their state of exploitation, make up the remaining 20 percent of total marine catches. This includes the 12.7 percent of the world marine catches corresponding to those catches for which no proper scientific data are monitored or investigated so as to provide a reliable assessment of their state 
of exploitation (Zhang and Marasco, 2008).

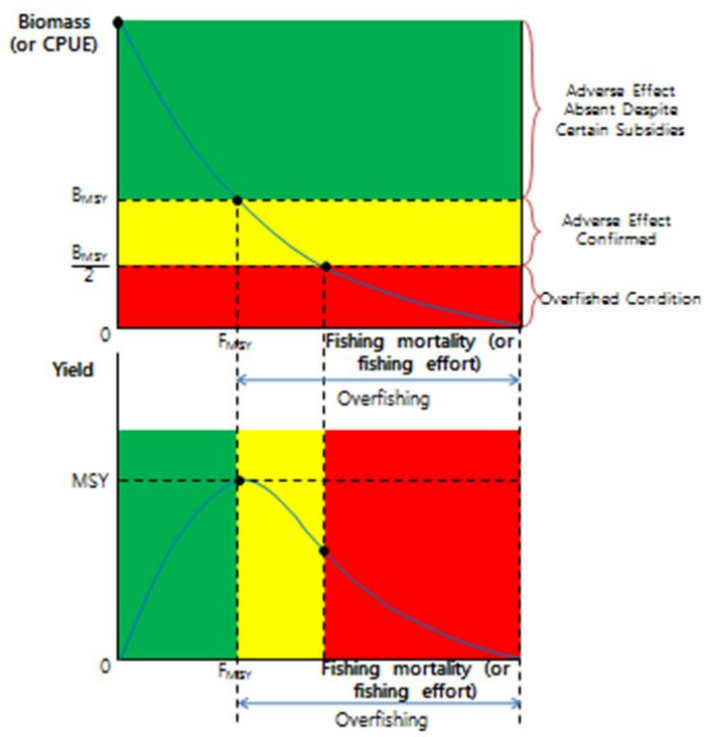

[Fig. 1] Diagram showing the dynamic behavior of overfishing and overfished condition

At the same time, however, concerns have been raised as to the logistical and practical difficulties countries may face in conducting stock assessments: that 1) a stock assessment requires expensive data and advanced scientific capacity; and that 2) such a stock assessment becomes more difficult where the nature of a fishery is small-scale, multi-species catching operation. In this situation, there do not exist sufficiently detailed studies to identify whether any fishing operation is indeed in the status of overfishing or not for a variety of fisheries including multi-species fisheries, data-poor artisanal fisheries as well as traditional single species fisheries. Furthermore, few studies have been conducted to clearly identify the status of the stock biomass to determine whether it is in a healthy condition or in an over-fished condition, and whether the current fishing operation is in the status of overfishing or not (US NPFMC, 2012,
Harley et al., 2010).

\section{Objectives of the paper}

The objective of this paper is to propose an approach to identify the status of the stock biomass to determine whether it is in a healthy condition or in an over-fished condition, and whether the current fishing operation is in the status of overfishing or not, by fully accounting for the data-poor and multi-species situations as well. This method is then applied to actual single- and multi- stocks under various levels of data availability to demonstrate the usefulness and feasibility of the proposed approach.

\section{II . Methods}

\section{Approaches for determining overfishing and overfished condition}

The dynamic effects of fishing on a fish stock and the resulting catches from the stock can be simply explained in the diagram provided in [Fig. 1]. [Fig. 1] is a conceptual diagram showing dynamic behavior of the overfishing and overfished condition. When fishing starts, the fish stock is abundant and the biomass of the stock is almost in the virgin state, and the catches taken by individual vessels are reasonably high, although the total catch is low because there are few vessels engaged in fishing activities (with a low fishing effort). As the amount of fishing increases, it will begin to gradually affect the fish stock, reducing its biomass and the average yield taken by a unit amount of fishing. As a result an increased amount of fishing will continuously reduce the biomass and will give less than a proportional increase in yield, and the curve of yield, as a function of the amount of 
fishing, will be ultimately reaching the peak, at which the greatest yield (the maximum sustainable yield, MSY) occurs by an optimum fishing effort (f $=\mathrm{fMSY})$. More fishing beyond this level $(\mathrm{f}>$ fMSY) will decrease the yield.

If a fish stock remains in the green zone of the diagram, the fish stock is in good health $(\mathrm{B}>$ BMSY) and the fishing effort at this level ( $f<$ fMSY) does not reduce the biomass. On the other hand, if the fish stock moves to the yellow zone in the diagram, the stock is in a lightly over-fished condition (BMSY $>\mathrm{B}>0.5 \mathrm{BMSY}$ ). If the fish stock is found to be in the red zone, however, the stock is now in a seriously over-fished condition ( $\mathrm{B}<0.5 \mathrm{BMSY}$ ), which is regarded as 'beyond the limit reference point' (MSC, 2010) or as 'an over-fished status' (US NPFMC, 2012).

[Fig. 1] can be easily generated from surplus production models such as Fox (1970) model using time-series catch and fishing effort data or Zhang et al. (1991) model using time-series biomass and fishing mortality. If these time-series data are not available, equilibrium biomass (or spawning biomass) per recruit model of Beverton and Holt (1957) can be used to generate the conceptual diagram using only population ecological parameters on growth, mortality, gear selectivity, and maturity.

It has been noted that many developing countries have expressed their concerns regarding the practical and logistical difficulties in carrying out a stock assessment: arguing that 1) such a stock assessment requires expansive data and highly advanced scientific capacity, which would mean that a sufficient transition time is necessary with the sufficient technical assistance for them to improve their scientific capacity; and that 2) such a stock assessment is more difficult in a situation where the nature of a fishery is small-scale, multi-species catching. In fact, however, there exist various alternative approaches to a stock assessment in data-deficient environment which can be utilized by developing countries.

\section{Single species using time-series catch and fishing effort data}

In a standard stock assessment, an attempt is usually made to estimate stock biomass and fishing mortalities of a given species or a unit stock, and this information is then used to estimate management parameters such as maximum sustainable yield (MSY) and their corresponding fishing mortality (FMSY). However, often times a situation arises where data for estimating biomass and fishing mortality are not available, or where scientific capacity to estimate such biomass and fishing mortality is not sufficient enough to carry out the task and complete the analysis. In this situation, catch per unit of effort (CPUE) can be utilized as a surrogate of biomass, and fishing effort as a surrogate of fishing mortality, respectively. CPUE is the value of catch simply divided by fishing effort, so these data are available for any kind of fisheries, since catch and effort data are considered to be just basic statistics commonly collected or monitored in the fisheries. Also, the level of data analysis for this assessment requires only basic statistical knowledge to estimate two parameters of a linear regression. In this instance, even a computer may not be necessary to conduct the required computation, and only a scientific calculator may be sufficient to complete the analysis.

We can make the stock-fishing intensity diagram generated from the surplus production model of Fox (1970) using time-series catch and fishing effort data as Equation (1) below: 


$$
U=U_{\infty} e^{-\left(\frac{q}{r}\right) f}
$$

where, $U$ is catch per unit of effort, $f$ is fishing effort, $U \infty$ is the maximum catch per unit of effort, $\mathrm{q}$ is catchability coefficient, and $\mathrm{r}$ is intrinsic rate of population growth. Equation (1) can be modified to be a linear equation to estimate parameters. Natural logarithm of catch per unit of effort, $\ln (\mathrm{U})$, is regarded as $\mathrm{Y}$ and effort $\mathrm{f}$ is regarded as $\mathrm{X}$, and then the slope $\mathrm{a}$ and Y-intercept $b$ can be estimated from a linear regression analysis of $\ln (\mathrm{U})=\mathrm{a}+\mathrm{bf}$.

The equilibrium yield $(\mathrm{Y})$ can be expressed as Equation (2) below:

$$
Y=U_{\infty} e^{-\left(\frac{q}{r}\right) f} \cdot f
$$

\section{Multi-species using aggregated catch and fishing effort data}

In a small-scale, multi-species fishery situation, a multi-stock assessment approach can be adopted by utilizing aggregated catch and fishing effort data, instead of using single-stock's catch and effort to make a similar diagram based on Equation (1). When a fishery is targeting multi-species, or when the fish catches are composed of multiple species in nature, catch as a unit species group can be aggregated to carry out a stock assessment. Contemporarily, this kind of simple management practice is common in multi-species, small-scale fisheries of the world oceans. Also, if more precise fishing effort data are not available, the number of fishing boats can then be utilized as a rough fishing effort index, although the number of fishing boats does not necessarily provide a good index in terms of accuracy. In this case, more accurate and precise data such as the number of boat-fishing days or the number of total hauls should be collected to ensure a better assessment afterward.

\section{Single species using fish length data with population parameters}

In the case where time-series catch and fishing effort data are not available, the stock condition can still be assessed using fish length composition data, employing some known population ecological characteristics of the assessed fish species (such as body growth and survivorship patterns) from literature or D-base. The diagram can be created from the equilibrium biomass per recruit model of Beverton and Holt (1957) expressed as Equation (3) below:

$$
\frac{B}{R}=W_{\infty} \cdot \exp \left[-M \cdot\left(t_{c}-t_{r}\right)\right] \cdot \sum_{n=0}^{3} \frac{U_{n} \cdot \exp \left[-n \cdot K \cdot\left(t_{c}-t_{0}\right)\right]}{F+M+n \cdot K} \ldots .
$$

where, $\mathrm{W}_{\infty}$ is maximum weight of fish species, $\mathrm{F}$ is fishing mortality, $\mathrm{M}$ is natural mortality, tc is age of first capture, tr is age of recruitment, to is von Bertalanffy parameter and the theoretical age at which the fish would have zero length if it had always grown as described by the von Bertalanffy equation, $\mathrm{K}$ is von Bertalanffy growth rate, $\mathrm{Un}$ is integration coefficient; $\mathrm{U} 0=1, \mathrm{U} 1=-3, \mathrm{U} 2=3$, and $\mathrm{U} 3=-1$. The equilibrium yield per recruit $(\mathrm{Y} / \mathrm{R})$ will be expressed as Equation (4) below:

$$
\frac{Y}{R}=F \cdot W_{\infty} \cdot \exp \left[-M \cdot\left(t_{c}-t_{r}\right)\right] \cdot \sum_{n=0}^{3} \frac{U_{n} \cdot \exp \left[-n \cdot K \cdot\left(t_{c}-t_{0}\right)\right]}{F+M+n \cdot K}
$$

\section{Application}

The purpose of this application is to demonstrate the applicability of the method explained in the previous section. 
1. Single species using time-series catch and fishing effort data : Eastern Pacific yellowfin tuna

[Fig. 2] shows the assessed stock-fishing intensity diagram generated from the surplus production model of Fox (1970) using time-series catch and fishing effort data for the east Pacific yellowfin tuna (Pella and Tomlinson, 1969) shown in $\langle$ Table 1>. [Fig. 2] demonstrates that catch and fishing effort data could be used for stock assessment, although biomass and fishing mortality data will offer better indices to understand the status of stock and the current condition of fishing intensity. In fact, catch and fishing effort data are basic statistics which can be easily obtained from a fishery. In [Fig. 2] the most recent year, 1967, was in the green zone of the upper panel which means 'not overfished stock', as well as was in the green zone of lower panel which means 'no overfishing is going on the stock' by the fishery. Based on this assessment, it will be possible to conclude that

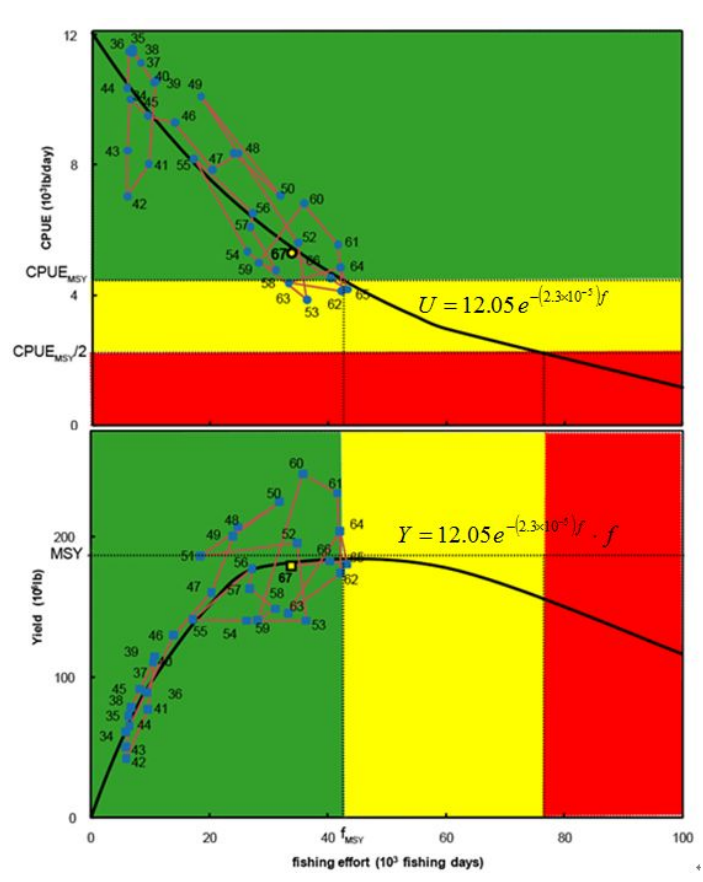

[Fig. 2] Equilibrium relative biomass (CPUE) and yield curves using Fox (1970) model for the eastern Pacific yellowfin stock (Data from Pella and Tomlinson, 1969)

$\langle$ Table 1> Input data used for surplus production model (Fox, 1970) to demonstrate single species using time-series catch and fishing effort data (Data from Pella and Tomlinson, 1969)

Eastern Pacific yellowfin

\begin{tabular}{|c|c|c|c|c|c|c|c|c|}
\hline Year & $\begin{array}{l}\text { Catch } \\
\left(10^{3} \mathrm{lb}\right)\end{array}$ & $\begin{array}{c}\text { Effort } \\
\left(10^{3} \text { fishing }\right. \\
\text { days })\end{array}$ & Year & $\begin{array}{l}\text { Catch } \\
\left(10^{3} \mathrm{lb}\right)\end{array}$ & $\begin{array}{c}\text { Effort } \\
\left(10^{3} \text { fishingd }\right. \\
\text { ays })\end{array}$ & Year & $\begin{array}{l}\text { Catch } \\
\left(10^{3} \mathrm{lb}\right)\end{array}$ & $\begin{array}{c}\text { Effort } \\
\left(10^{3} \text { fishingda }\right. \\
\text { ys })\end{array}$ \\
\hline 1934 & 60,913 & 5,879 & 1946 & 129,701 & 13,958 & 1958 & 148,450 & 31,135 \\
\hline 1935 & 72,294 & 6,295 & 1947 & 160,151 & 20,383 & 1959 & 140,484 & 28,198 \\
\hline 1936 & 78,353 & 6,771 & 1948 & 206,993 & 24,781 & 1960 & 244,331 & 35,841 \\
\hline 1937 & 91,522 & 8,223 & 1949 & 200,070 & 23,923 & 1961 & 230,886 & 41,646 \\
\hline 1938 & 78,288 & 6,830 & 1950 & 224,810 & 31,856 & 1962 & 174,063 & 42,248 \\
\hline 1939 & 110,418 & 10,488 & 1951 & 186,015 & 18,403 & 1963 & 145,469 & 33,303 \\
\hline 1940 & 114,590 & 10,801 & 1952 & 195,277 & 34,834 & 1964 & 203,882 & 42,090 \\
\hline 1941 & 76,841 & 9,581 & 1953 & 140,042 & 36,356 & 1965 & 180,086 & 43,228 \\
\hline 1942 & 41,965 & 5,961 & 1954 & 140,033 & 26,288 & 1966 & 182,294 & 40,393 \\
\hline 1943 & 50,058 & 5,930 & 1955 & 140,865 & 17,198 & 1967 & 178,944 & 33,814 \\
\hline 1944 & 64,869 & 6,475 & 1956 & 177,026 & 27,205 & & & \\
\hline 1945 & 89,194 & 9,377 & 1957 & 163,020 & 26,768 & & & \\
\hline
\end{tabular}


the yellowfin tuna stock was in a healthy condition with a higher than CPUEMSY in 1967 (upper panel of [Fig. 2]) and that this yellowfin tuna fishery was conservatively managed with a smaller than FMSY in 1967 (lower panel of [Fig. 2]).

\section{Multi-species using aggregated catch and fishing effort data: Java Sea multi-species by trawl fishery}

[Fig. 3] shows a similar diagram with [Fig. 2] using aggregated catch and fishing effort data for Java Sea trawl fishery using data (Dwiponggo, 1979) in <Table 2> based on Equation (1). In [Fig. 3] the most recent year, 1977, was in the yellow

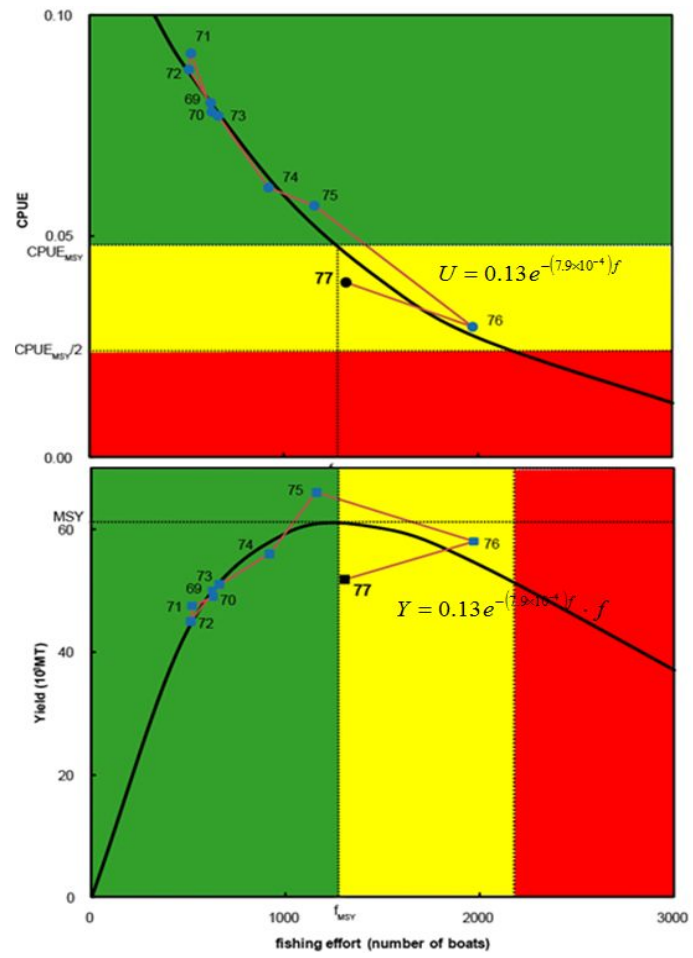

[Fig. 3] Equilibrium relative biomass (CPUE) and yield curves using Fox (1970) model for the multi-stocks by the Java Sea trawl fishery (Data from Dwiponggo,1979) zone of the upper panel which means 'not overfished, but dangerous to be overfished multi-stocks', and it was also in the yellow zone of the lower panel which means 'light overfishing is going on the multi-stocks' by the fishery. Based on the assessment, we can conclude that the condition of multi-stock was in a little risky condition with the CPUE of 1977, which was between CPUEMSY and CPUEMSY/2 (upper panel of [Fig. 3]) and that the Java Sea trawl fishery was not properly managed with the larger than FMSY in 1977 (lower panel of [Fig. 3]).

$<$ Table 2> Input data used for surplus production model (Fox, 1970) to demonstrate multi-species using aggregated catch and fishing effort data (Data from Dwiponggo,1979)

Java Sea trawl multi-species

\begin{tabular}{ccc}
\hline Year & $\begin{array}{c}\text { Catch } \\
\left(10^{3} \mathrm{mt}\right)\end{array}$ & $\begin{array}{c}\text { Effort (Number of } \\
\text { fishing vessel) }\end{array}$ \\
\hline \hline 1969 & 50 & 623 \\
\hline 1970 & 49 & 628 \\
\hline 1971 & 47.5 & 520 \\
\hline 1972 & 45 & 513 \\
\hline 1973 & 51 & 661 \\
\hline 1974 & 56 & 919 \\
\hline 1975 & 66 & 1,158 \\
\hline 1976 & 58 & 1,970 \\
\hline 1977 & 52 & 1,317 \\
\hline
\end{tabular}

3. Single species using fish length data with population parameters: small yellow croaker in Korean waters

[Fig. 4] shows the assessed diagram from the equilibrium biomass per recruit model of Beverton and Holt (1957) expressed as Equation (3). [Fig. 4] can be made using only fish length composition 


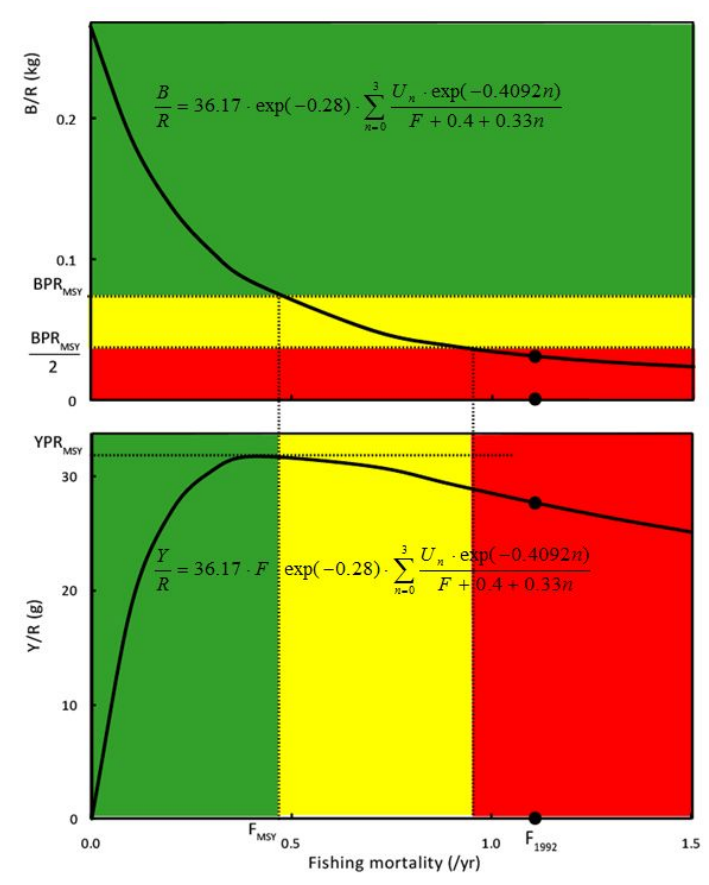

[Fig. 4] Equilibrium biomass per recruit (BPR) and yield per recruit ( $Y / R$ ) curves using Beverton and Holt (1957) model for the Korean small yellow croaker stock (Data from Zhang et al., 1992)

data for estimating the age at first capture and the current fishing mortality, together with population ecological parameters on growth and natural mortality (Zhang et al., 1992) in <Table 3>. The input data of the current fishing mortality and the age at first capture can be estimated from a length-converted catch curve analysis (Zhang, 2010). In [Fig. 4], the current BPR and YPR are expected values from the model under the equilibrium assumption of the fish population. In [Fig. 4] the assessed year, 1992, was in the red zone both of the upper and lower panels, which

means 'overfished stock' and 'overfishing is going on the stock' by the fishery. Based on this assessment, it will be possible to conclude that the small yellow croaker stock was in an over-fished condition with the lower than BPRMSY in 1992, which was in the red zone (upper panel of [Fig. 4]) and that the croaker fishery was not managed properly since the fishing operation was the status of overfishing with the F1992 in the red zone (lower panel of [Fig. 4]).

$<$ Table 3> Input data used for equilibrium biomass per recruit analysis (Beverton and Holt, 1957) to demonstrate single species using fish length data with population parameters (Data from Zhang et al., 1992)

Korean small yellow croaker

\begin{tabular}{ll|ll}
\hline $\mathrm{W}_{\infty}$ & 455.77 gram & $\mathrm{M}$ & $0.4 /$ year \\
\hline $\mathrm{K}$ & $0.33 /$ year & Current $\mathrm{F}$ & $1.11 /$ year \\
\hline $\mathrm{t}_{0}$ & -0.24 year & Current $\mathrm{t}_{\mathrm{c}}$ & 1 year \\
\hline $\mathrm{t}_{\mathrm{r}}$ & 0.30 year & & \\
\hline
\end{tabular}

\section{Discussion}

Fisheries resources have been being depleted in world oceans. The global community is currently encountering three threats in fisheries: overfishing, overcapacity and ecosystem damage from fishing. Although fisheries management has been conducted, the percentage of overexploited stocks is continuously increasing from $10 \%$ in 1974 to $35 \%$ in 2008. The current phenomenon has been considered to be caused by the following two reasons: the first is the spread of the IUU fishing, and the other is ineffective fisheries management. Therefore, it is critical for the global community to find a way to improve the fisheries management system by including such core elements as effective eradication of the IUU fishing and a precautionary management based on the identification of 
overfishing and overfished condition of fisheries resources.

The conceptual diagram in [Fig. 1] shows that the distinction between the overfished condition and the adverse effect situation and, more critically, confirmation of the adverse effect situation flowing from overcapacity and over-fishing are both scientifically and logistically feasible. This is an important confirmation that a determination whether a particular fish stock is in an overfished condition can be rendered based on scientific data and analyses. Furthermore, [Fig. 1] can be produced for each separate fish stock or multi-stocks in question in a particular maritime zone. As long as a fisheries management system for the stock and the relevant maritime zone is in place, the data for such a diagram can be readily produced and reliably updated. Consequently, a diagram can be prepared for a situation existing at a particular point in time (for instance, January 2013) or in a sequential mode to reflect the changes or fluctuations during a certain period of time (for instance annual changes from January 2005 to January 2013).

The diagram in [Fig. 1] could be used to determine whether a fish stock is in a healthy condition or in an over-fished condition, and also whether the current fishing operation is the status of overfishing or not. As an example, when this diagram is applied to the currently on-going debate at the WTO's fisheries subsidies negotiation within the context of the Doha Development Agenda, in which the scientific possibility and practical feasibility of identifying an adverse effect on a particular fish stock or stocks, the green zone of the diagram indicates a situation where certain types of alleged subsidies do not cause the adverse effect through overcapacity and over-fishing even if the existence of a subsidy is confirmed within the meaning of the
WTO's Agreement on Subsidies and Countervailing Measures (Anonymous, 2007). On the other hand, the yellow zone indicates that the fish stock in question is in the condition of suffering from an adverse effect arising from overcapacity and over-fishing. So, when a fish stock is found to be located in the yellow zone and a subsidy program of a subsidizing country is confirmed to exist, unless compelling explanations are provided by the subsidizing country, a reviewing WTO dispute settlement panel in charge of the fisheries subsidies dispute at hand will have to determine the existence of an adverse effect through overcapacity and over-fishing as a result of the challenged subsidy. The remedy in this situation should be withdrawal of the measure, which is effectively the same as the remedy for the subsidies falling under a prohibited category situation where withdrawal of the subsidy measure is automatically required.

On the other hand, if the fish stock is found to be in the red zone, this indicates that the stock is already in an overfished condition. In this situation, any subsidy of a subsidizing country that affects the fish stock (or causes such a situation) should be prohibited ex ante - which basically corresponds to the situation of a prohibited subsidies category in the proposed draft text of the Chairman of the WTO's fisheries subsidies negotiations where a prohibited subsidy-only approach is basically adopted. For this analysis, a diagram can be prepared for an each individual stock. This analysis may be able to ensure a reliable test for an overfished condition as the term has been used in the context of the WTO fisheries subsidies negotiations. As regards the adverse effect test, diagrams for multiple representative stocks would have to be prepared and analyzed. The diagram shows that the adverse effect test is logistically and 
scientifically feasible with a similar degree of analysis. The diagram also indicates the adverse effect test's prospective promotional effect for strengthening and expanding the fisheries management system on a global level, which is considered to be a cornerstone of preventing and slowing down the global overfishing and overcapacity.

In determining whether a stock in question is over-fished or not, and whether the optimum level of fishing effort is properly regulated or not, an efficient fisheries management system should be established with at least the following three core minimum elements, namely 1) stock assessment and data collection mechanisms, 2) conservation and management measures, and 3) compliance measures. In the long run, these three core elements should be universally applicable to all situations of fisheries. On the other hand, the methods for stock assessments and tools for management could be different, depending upon the data availability and the level of the scientific capacity. For example, regarding data-deficient, small-scale fisheries, it may be possible to choose proper methods of the stock assessment which would be less complicated and which would require a less amount of data. In this case, proxies may be utilized in the place of standard reference points.

[Fig. 1] can be easily generated only using time-series catch and fishing effort data or time-series biomass and fishing mortality. If these time-series data are not available, only basic population ecological parameters are required for this analysis, which can be estimated from three core minimum elements mentioned above. Even if monitoring fishing effort data is not necessarily easy for some small-scale fisheries, the number of fishing boats can be used to make the diagram for a multispecies situation as shown in [Fig. 3].
In some stock assessment systems, there are many tiers in the estimation of reference points on the basis of the availability of information. By way of example, Korea has a 5-tier assessment system (Zhang and Marasco, 2003), and the North Pacific Fisheries Management Council of the United States has a 6-tier assessment system (US NPFMC, 2012). And recently, the Marine Stewardship Council (MSC) has developed a Risk-Based Framework (RBF) for assessing data-deficient, small-scale fisheries.

\section{References}

Anonymous(2008). The Sunken Billions. The Economic Justification for Fisheries Reform. Agriculture and Rural Development, Sustainable Development Network, Advanced edition, The World Bank and FAO

Anonymous(2007). Draft Consolidated Chair Texts on the AD and SCM Agreement. WTO TN/RL/W/213. Beverton, Ray. J. J. and Sydeny .J. Holt(1957). On the dynamics of exploited fish populations. Fishery investigation, Series $\amalg$, Marine fisheries, Great Britain Ministry of Agriculture, Fisheries and Food. 19. 533.

Dwiponggo, A.(1979). Review of the demersal resources and fisheries in the Java Sea. Marine Fisheries Research Institute, Agency for Agricultural Research and Development, Ministry of Agriculture, Jakarta, Indonesia; 36.(Mimeo).

Food and Agriculture Organization(1995). Report of the Expert Consultation on Guidelines for Responsible Fisheries Management, FAO Fisheries Report No. 519. FAO, Rome.

Food and Agriculture Organization(2010). The state of world fisheries and aquaculture, 218.

Fox, William • W., Jr.(1970). An exponential surplus yield model for optimizing exploited fish populations, Trans, Amer. Fish. Soc., 90.

Harley, S. - S. Hoyle · P. Williams · J. Hampton, and P. Kleiber(2010). Stock assessment of bigeye tuna in the western and central Pacific Ocean, WCPFC- 
SC6-2010/SA-WP-04. 105.

Hilborn, Ray(2012). Overfishing: what everyone needs to know, Oxford University Press, 150pp.

Pella, J. J. and P. K. Tomlinson(1969). A generalized stock production model, Inter. Am. Trop. Tuna Comm. Bull.-; 13: 419 496.

US NPFMC(2012). Stock assessment and fisheries evaluation report for the groundfish resources of the Bering Sea/Aleutian Islands region, NPFMC, US, Anchorage, 2008.

Zhang, Chang-Ik - Gunderson Donald and Sullivan Patrick(1991). Using data on biomass and fishing mortality to stock production modeling of flatfish, Netherlands Journal of Sea Research, 27(3/4): 459 467.

Zhang, Chang-Ik $\cdot$ Kim Suam and Yoon Sung-Bong (1992). Stock assessment and management implications of small yellow croaker in Korean waters, J. Korean Fish. Soc. 25(4): 282 290.

Zhang, Chang-Ik(2010). Marine Fisheries Resource Ecology, Pukyong National University Press, Busan, Korea; 561.

Zhang, Chang-Ik and Marasco, Richard(2003). New approaches in fisheries assessment and management under the exclusive economic zone regime in Korea, Am. Fish. Soc. Symp. 38, 685 - 693.

Zhang, Chang-lk and Marasco, Richard(2008). A review of the current status of ecosystem-based fisheries assessment and management. KAST Review of Modern Science \& Technology, 4: $55 \sim 63$.

- 논문접수일 : 2013년 07월 01일

- 심사완료일 : 1차 - 2013년 09월 12일

- 게재확정일 : 2013년 09월 15일 